\section{Botanical roots}

\section{Sandra Knapp}

A Passion for Plants: From the Rainforests of Brazil to Kew Gardens. By Clive Langmead. Lion: 1995. Pp. 201. £16.99.

THERE are basically three types of biographies: those about politicians and other public figures written during their careers; those, often about scientific figures, written after a person's death and reviewing his or

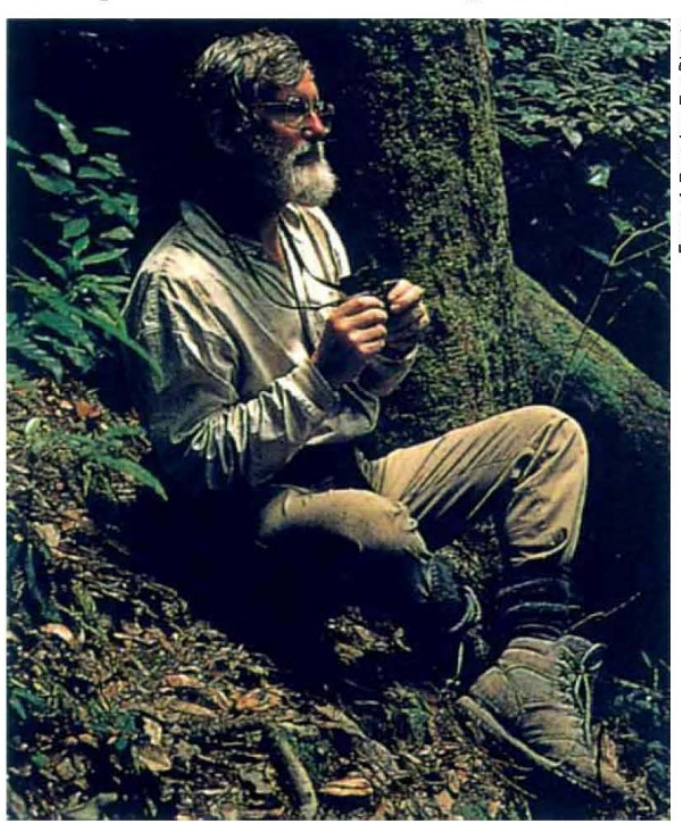

Man of vision - Ghillean Prance doing field work.

her life and achievements; and autobiographies, which provide a rare glimpse into the working of someone else's mind. This book is of the first sort. It is about the life and vision of Ghillean Prance the director of the Royal Botanical Gardens at Kew, rather than about Ghillean Prance the plant taxonomist. I am sure that this was the intention of the author, but I am left with the feeling that from a man as driven and as interesting as Prance there is still more to come.

The life described here is a fascinating one, full of adventure and hard work. The detail with which Prance's early life is portrayed makes the reader see the director of Kew as a man rather than a figurehead, although anyone who has had any contact with Prance already knows that he is a remarkably accessible, open and friendly figurehead. The emphasis on the pervasive influence of his strong Christian beliefs on his life both in and out of science (lives that in his case are not all that separable) is due to the importance with which he regards these beliefs and to the fact that the publisher specializes in Christian matters. At one point in his life, Prance considered ordination but was persuaded by his future father-in-law to pursue a career in botany and not to waste the gift he had for natural history.

Taxonomy and systematics are often seen as dull, parochial and irrelevant in this age of molecular biology and gene manipulation. With science very much being pushed towards wealth creation, we are in danger of losing sight of the true curiosity that drives the quest for scientific knowledge. This book, by virtue of being for a nonspecialist audience, shows clearly that the frontiers of discovery are not all in laboratories - they can also be found in the Amazon. The story of the pollination of Victoria amazonica, the giant Amazonian water lily, is a classic of botanical detective work. (The sequence was beautifully portrayed in David Attenborough's recent television series "The Private Life of Plants".) To discover that the beetle pollinators are trapped inside the flower for 18 hours while pollen is released, then let free to cross-pollinate other younger flowers, is neither trivial nor irrelevant; knowledge of such complex interactions and their mechanics and distribution will ultimately allow us to understand the world's great ecosystems. Sustainable development, the buzzword of the moment, can be achieved only by knowing what is in an area and how it works.

Knowledge about the names, relationships and interactions of plants and animals is the basis for all biology and is of crucial importance to the future of our own and other species. Prance has spent his career working from within to further these views and to make the plight of rainforests, particularly those of the Amazon, understandable to the 'man in the street'. His decision not to co-author with Robert Goodland Green Hell to Red Desert, one of the first books to warn of the threat of Amazonian rainforest development, allowed him to continue to work in Brazil, and to bring about changes he felt were essential to the future of the region.

As director of Kew, Prance has been able to spread his botanical message to an even broader audience. His decision to leave the New York Botanical Garden, where he had worked for 24 years, and come to Kew is portrayed as a decision for the good of botany rather than a personal career move. The directorship of Kew may well be the top botany job in the world, but his use of the position as a platform for educating people in all walks of life about the current grave environmental crisis shows great courage and dedication. I first met Prance while he was at New York, and his influence on my generation of botanists went far beyond the boundaries of the New York Botanical Garden.
Clive Langmead has produced an easy to read, interesting and somewhat eulogistic biography of an exceptional person. But while reading the book I found myself constantly annoyed by the lack of a personality shining through. I hope that one day Prance will write an autobiography and give us all the chance to see his mind at work. For I suspect that, like Richard Spruce, the famous Amazonian explorer to whom he is often compared, his own thoughts about his life are infinitely more interesting than someone else's. Prance is still young as scientists go, and his future years are sure to be just as surprising and fruitful as those that have passed.

Sandra Knapp is in the Department of Botany, The Natural History Museum, Cromwell Road, London SW7 5BD, UK.

Guide to Flowering Plant Families. By Wendy B. Zomlefer. University of North Carolina Press: 1994. Pp. 430. \$55 (hbk), \$27.50 (pbk).

GooD illustrations and clear and concise descriptions of the families of flowering plants are hard to find in one place. Time and again, I have gone back to my bible for this sort of synoptic information, Hutchison's Families of Flowering Plants, published in 1934 (with a second edition in 1959).

Zomlefer's book very neatly fills a gaping hole in the literature for the student of plant taxonomy and general botany. The book has a lucid and well written introduction to modern taxonomic methods, complete with a nonthreatening treatment of cladistics and its use in taxonomy. The families of flowering plants in the United States (including Florida that is, the subtropics) are then described, discussed and beautifully illustrated. The drawings alone make this book a treasure; they are clear, large and display all the diagnostic features necessary for the identification of plants in any particular family. The references included with each family description lead the student to the primary literature, and recent reorganizations and major taxonomic changes are fully discussed, such as those for the mints and verbenaceae (see P. Cantino, Ann. Missouri Bot. Gard. 79, 361; 1992).

The book is designed for the North American market, but would be useful anywhere. The illustrated glossary will make it invaluable for anyone trying to come to grips with the sometimes obscure world of botanical terminology (drawing of a trigonous stem jumps off the page). It is rare that a textbook is also an important reference work for the professional botanist, but Zomlefer has made the information presented here so accessible, authoritative and up to date that anyone enthusiastic about plants should have the volume on their shelves.

S. $K$.

NATURE $\cdot$ VOL $374 \cdot 13$ APRIL 1995 